\title{
Physiological and Biochemical Response of Probiotics and Phytogenic Inclusion as Growth Promoters on Growing Male Rabbits
}

\author{
Hala M. Arram ${ }^{1}$, Ahmed A. Radwan ${ }^{1}$, Abdelkarim I. M. El-Sayed ${ }^{1}$, Fawkya A. Elhodairy ${ }^{2}$, Omer A.Farid, \\ 2, Mahmoud M. I. Amer'. \\ ${ }^{1}$ Animal production department, Faculty of Agriculture, Benha University, Egypt, ${ }^{2}$ Physiology department, \\ National Organization for Drug Control and Research, Egypt. \\ Corresponding author: Abdelkarim 54@ yahoo.com
}

\begin{abstract}
This experiment was conducted to study the effect of the inclusion of herbal supplementation (Thyme) and probiotic lactobacillus acidophilus on productive, physiological and immunological capabilities of growing rabbit after fatting period. It has been used in this research 30 weaning New Zealand White (NZW) rabbits at 35 days of age divided to 5 groups, 6 for each. Group 1 served as control group; Group 2 treated with $20 \mathrm{mg} / \mathrm{kg}$ b.w. of thyme aqueous extract; Group 3, 4 and 5 treated with 20, 40, 60 million bacterial count $/ \mathrm{kg}$ b.w. of lactobacillus acidophilus, respectively. The experiment lasted for 2 month and growth performance, blood samples, liver and brain tissue were collected at the end of experiment. Revealed data demonstrated that body weight, growth performance, body weight gain, liver functions, metabolic function, and oxidative stress markers were generalized stimulated with thyme $(20 \mathrm{mg} / \mathrm{kg}$ b.w.) and probiotics low dose (PBLD,20 million bacterial count $/ \mathrm{kg} \mathrm{b.w)} \mathrm{and} \mathrm{confirmed} \mathrm{via} \mathrm{liver} \mathrm{histological} \mathrm{examination.} \mathrm{In} \mathrm{contrast} \mathrm{probiotics} \mathrm{medium} \mathrm{dose} \mathrm{(PBMD,} 40$ million bacterial count $/ \mathrm{kg}$ b.w) and Probiotics high dose (PBHD, 60 million bacterial count $/ \mathrm{kg}$ b.w.) disrupt most physiological, biochemical and histological parameters. Thus, the study concluded that thyme $(20 \mathrm{mg} / \mathrm{kg}$ b.w.) and probiotic low dose (20 million bacterial count $/ \mathrm{kg}$ b.w.) have powerful stimulatory effect in physiological and immunological performance after two months of treatments.
\end{abstract}

Key words: Thyme, Probiotic, New Zealand White (NZW) rabbits, oxidative stress markers.

\section{Introduction}

Antibiotic growth promoter is used to describe any medicine that destroys or inhibits bacteria and subsequent stimulate health performance and muscle building for domestic farm animals (Thomke and Elwinger, 1998). Worthily, antibiotic growth promoters are used to increase growing, digestion, and decrease most gastrointestinal tract disturbance. Many side effects befall antibiotics specially for destroy and kill benefit and pathogenic bacteria thus, large and most ruminants has many drawback for its effects (Allen et al .2013).

Recently, natural probiotics act as a natural growth promoters or non-antibiotic growth promoters. They are commonly regarded as favorable alternatives to antibiotic growth promoters in livestock production. The main advantage of natural growth promoters are to low risk regarding bacterial resistance or undesired residues in animal products such as meat, milk or eggs. Generally, probiotics are live microorganisms which support the development of a beneficial gut microflora. Probiotic bacteria (e.g. from the genera Lactobacillus, Bifidobacterium, Enterococcus) counteract undesired microorganisms such as Salmonella or E. coli by blocking receptors on the gut wall, production of antimicrobial substances or activation of the immune system (Richards et al. 2005).

Phytogenics are derived from herbs, spices or aromatic plants and have shown antimicrobial, antifungal, antiviral, antioxidant or sedative properties. They are known for their appetizing effects, since they increase the palatability of the feed and stimulate endogenous digestive enzymes. Moreover, phytogenics have a pronounced impact on the gut microflora. (Männer, 2011). The aim of the present investigation was to study the effect of the inclusion of herbal supplementation (Thyme) and probiotic lactobacilli compared with control group on productive, physiological and immunological capabilities of growing rabbit after fattening period

\section{Materials and methods}

This experiment was done30 on New Zealand White (NZW) rabbits of one months (35 days) of age and average weight of $500 \mathrm{~g}$. The animals were randomly divided into five groups, each one comprise 6 animals. The $1^{\text {st }}$ group preserved as normal control, $2^{\text {nd }}$ group treated with $20 \mathrm{mg} / \mathrm{kg}$ b.w. of Thyme vulgaris aqueous extract, $3^{\text {rd }}$ group treated with 20 million bacterial count (MBC)/kg b.w, $4^{\text {th }}$ group treated with $40 \mathrm{MBC} / \mathrm{kg}$ b.w, $5^{\text {th }}$ group treated with $60 \mathrm{MBC} / \mathrm{kg}$ b.w. The experiment lasted for 2 months after weaning from mothers cages. Blood samples, liver and brain tissue were collected after two month of treatment for physiological, biochemical, and histopathological examination. The experimental rabbits were grouped and housed in a conventional clean facility according to the guidelines of the Institutional Animal Ethics 
Committee of NODCAR. All the experimental procedures were carried out in accordance with international guide-lines for the care and use of laboratory animals.

\section{Herbals extraction:}

Approximately $100 \mathrm{~g}$ of Thyme vulgaris leaves was placed in a clean, flat-bottomed glass container and soaked in ten volume of distilled water. The container with its contents was sealed and kept for 3 days. Then extraction was carried out using ultrasonic sound bath accompanied by sonication (40 minutes). The content filtrated by a piece of clean, white cotton material. The extract then was filtered through Whatman filter paper (Bibby RE200, Sterilin Ltd., UK) and dried by electric oven at $45^{\circ} \mathrm{C}$ temperature and continued up to obtain aqueous $(14.95 \mathrm{~g})$ extract. The gummy extract was stored in an air tight container (Algohary et al. 2016).

\section{Body weight and daily weight gain:}

Body weight and daily weight gain were determined at the beginning of experiment and after two month of treatment at the end of experiment. Daily weight gain was calculated by difference between final and initial weight divided by 60 days

\section{Measurement of blood Biochemical parameters: \\ Measurement of serum liver function enzymes:}

Hepatic dysfunction was assessed by measuring

the elevation in serum levels of Aspartate

transaminase (AST) and alanine transaminase (ALT) using commercially available kits. The results were expressed in u/L. (Reitman and Frankel, 1957).

Serum total protein and albumin determined using commercially available kits according to the method of Doumas et al. (1971). The globulin value was obtained by subtracting the value of albumin from the corresponding value of total protein. The albumin to globulin ratio $(\mathrm{A} / \mathrm{G})$ was calculated by dividing $\mathrm{A} / \mathrm{G}$ values. The results were expressed in $\mathrm{g} / \mathrm{L}$ according to Bradford (1976).

Determination of Metabolic hormones Triiodothyronine ( $\left.\mathrm{T}_{3}\right)$, Thyroxin $\left(\mathrm{T}_{4}\right)$, and Thyroid stimulating hormone (TSH):

Determination of serum $\mathrm{T}_{3}$ and $\mathrm{T}_{4}$ (Saxema $\boldsymbol{e t}$ al., 1968) TSH (Olayemi, 2007) by ELISA (Enzyme Linked Immunosorbant Assay), the kit was obtained from Fortrees Diagnostic Limited, United Kingdom and North Ireland.

Determination of oxidative stress markers: Determination of Malondialdehide (MDA) in liver tissue by HPLC:

Malondialdehide (MDA) standard was prepared by dissolving $25 \mu \mathrm{L} \quad 1,1,3,3$ tetraethoxypropane (TEP) in $100 \mathrm{ml}$ of distilled water to give $1 \mathrm{mM}$ stock solution. Working standard was prepared by hydrolysis of $1 \mathrm{ml}$ TEP stock solution in $50 \mathrm{ml} 1 \%$ sulfuric acid and incubation for $2 \mathrm{~h}$ at room temperature. The resulting MDA standard of 20 $\mathrm{nmol} / \mathrm{ml}$ was further diluted with $1 \%$ sulfuric acid to yield the final concentration of $1.25 \mathrm{nmol} / \mathrm{ml}$ to get the standard for the estimation of total MDA (Karatep, 2004). The samples were analyzed on an Agilent HP 1100 series HPLC apparatus (USA). The analytical column Supelcosil C18 (5 $\mu \mathrm{m}$ particle and $80 \mathrm{~A}^{\circ}$ pore size $)(250 \times 4.6 \mathrm{ID})$. Mobile phase consists of $30 \mathrm{mmol} \mathrm{KH}_{2} \mathrm{PO}_{4}$ and methanol $(65 \%$ $35 \%, \mathrm{H}_{2} \mathrm{PO}_{4}$ by $\mathrm{pH} 4$ ), and the mobile phase at a 1.5 $\mathrm{ml} / \mathrm{min}$ flow rate, wavelength $250 \mathrm{~nm}$. According to the method of Karalas et al. (2002).

Determination of oxidized glutathione (GSSG) and reduced glutathione (GSH) in liver tissue by HPLC:

The thiols compounds of oxidized and reduced glutathione were detected by HPLC using the method of Jayatilleke and Shaw (1993). Glutathione (oxidized and reduced) reference standard purchased from Sigma Chemical Co. Dissolved in $75 \%$ methanol in stock $1 \mathrm{mg} / \mathrm{ml}$ and diluted before application to HPLC. The HPLC system of Agilent consisted of quaternary pump, a column oven, Rheodine injector and $20 \mu \mathrm{l}$ loop, UV variable wavelength detector. The report and chromatogram taken from Chemstation program purchased from Agilent. Synerji RP Max column 3.9 at wavelength $210 \mathrm{~nm}$ with flow rate $2 \mathrm{ml} / \mathrm{min}$ was used. Pot. Phosphate buffer - acetonitrile at PH 2.7 was used as an isocratic mobile phase.

\section{Determination of nitrite / nitrate (NO) of liver tissue by HPLC}

Nitrites and nitrate was determined according to the method of Papadoyannis et al. (1999) by HPLC. Sodium nitrite and sodium nitrate used for the reference standard preparation with stock concentration $1 \mathrm{mg} / \mathrm{ml}$. A standard mixture of nitrite and nitrate was used to determine the retention times and separation of the peaks. Nitrite and nitrate concentrations were equal in the mixture solution. HPLC analysis: The samples were analyzed on an Agilent HP 1200 series HPLC apparatus (USA). The analytical column was anion exchange PRP-X100 Hamilton, $150 \times 4.1 \mathrm{~mm}, 10 \mu \mathrm{m}$. The mobile phase was a mixture of $0.1 \mathrm{M} \mathrm{NaCl}$ - methanol, at a volume ratio 45:55. The flow rate of $2 \mathrm{~mL} / \mathrm{min}$, wavelength adjusted to $230 \mathrm{~nm}$.

Determination of serotonin [5-hydroxytryptamine (5HT)] in brain tissue by HPLC:

The HPLC system consisted of quaternary pump; a column oven, Rheodine injector and $20 \mu \mathrm{l}$ loop, UV variable wavelength detector. The report and chromatogram taken from data acquisition program purchased from chemstation. The sample was immediately extracted from the trace elements and lipids by the use of solid phase extraction Chromabond column NH2 phase cat. No.730031. the 
sample was then injected directly into an AQUA column $150 \mathrm{~mm} 5 \mu \mathrm{C} 18$, purchased from Phenomenex, USA under the following conditions: mobile phase $20 \mathrm{mM}$ potassium phosphate, $\mathrm{pH} 2.5$, flow rate 1.5ml/min, UV $190 \mathrm{~nm}$. (Pagel et al. 2000).

\section{Histopathological examination}

Samples were taken from the liver of rabbits in different groups and fixed in $10 \%$ formal saline for twenty four hours. After that all tissue washed via tap water then serial dilutions of alcohol to dehydrate samples. Cleared specimens embedded in xylene then paraffin twenty four hours at $56^{\circ} \mathrm{C}$ in hot air oven. Paraffin blocks were prepared for sectioning at $4 \mu \mathrm{m}$ by slidge microtome. The obtained tissue sections were deparaffinized and stained on glass slide by hematoxylin and eosin stains for histopathological examination via electric light microscope according to Banchroft et al. (1996).

\section{Statistical analysis:}

Statistical analysis of the obtained data was performed using the general linear model (GLM) produced by Statistical Analysis Systems Institute (SAS, 2004). Significant differences among means were evaluated using Duncan's Multiple Range Test. The following linear model was applied:

Yij $=\mu+\alpha i+\xi i j$ where: $Y i j=$ Observation measured; $\mu=$ Overall mean; $\alpha \mathrm{i}=$ Effect of treatment; $\xi \mathrm{Ij}=$
Experimental error assumed to be randomly distributed $(\sigma 2=0)$.

\section{Results:}

\section{1- Body weight and daily gain:}

As shown in Table 1 generalized increase $(\mathrm{P}<0.05)$ in body weight and body weight gain in groups treated with Thyme and PBLD in comparing with control group and did not show any significant in other groups after two month of treatments. In addition, thyme and PBLD showed significant differences increase of body weight gain in comparing with control group. In contrast, PBMD and PBHD did not show any significant effect compared with control group.

\section{2- Liver function:}

The obtained biochemical data in Table 2 did not show any significant effect of thyme and PBLD treatment in liver function such as ALT and AST. On the other hand, PBHD showed significant hepatocytes infiltration resembling in AST concentration. Level of protein production resembling in TP, Glob and A/G showed significant increase $(\mathrm{P}<0.05)$ in thyme group in comparing with control group. Indeed, PBLD showed stimulation in protein production in comparing with control group but PBMD and PBHD showed mild inhibition $(\mathrm{P}>0.05)$ in protein production in comparing with control group.

Table1. Effect of thyme, low, medium, and high dose of probotics on growing rabbit's growth after two months of treatment.

\begin{tabular}{lcc}
\hline \multicolumn{1}{c}{ Groups } & $\begin{array}{c}\text { Body weight }(\mathbf{g}) \\
\text { after 2month of treatment }\end{array}$ & $\begin{array}{c}\text { body weight gain(g/day)at } \\
\mathbf{4 - 1 2} \text { WKs }\end{array}$ \\
\hline Control & $1923 \pm 52.3 \mathrm{~b}$ & $16.7 \pm 0.448 \mathrm{~b}$ \\
Thyme & $1984 \pm 52.68 \mathrm{ab}$ & $19.5 \pm 0.549 \mathrm{a}$ \\
PBLD & $2099 \pm 59.33 \mathrm{a}$ & $20.2 \pm 0.576 \mathrm{a}$ \\
PBMD & $1949 \pm 52.2 \mathrm{ab}$ & $16.6 \pm 0 \quad .44 \mathrm{~b}$ \\
PBHD & $1920 \pm 52.36 \mathrm{~b}$ & $15.5 \pm 0.417 \mathrm{~b}$ \\
\hline
\end{tabular}

Data are expressed as Mean \pm S.E.M for 6 rabbits /group.

Theme = Thyme extract $20 \mathrm{mg} / \mathrm{kg}$ b.w, PBLD= Probiotics low dose $20 \mathrm{MBC} / \mathrm{kg}$ b.w, PBMD =Probiotics medium dose,40 $\mathrm{MBC} / \mathrm{kg} \mathrm{b.w)}$ and PBMD Probiotics high dose (PBHD, $60 \mathrm{MBC} / \mathrm{kg} \mathrm{b.w)}$.

$\mathrm{a}, \mathrm{b}, \mathrm{c}$. means having different superscript letters in the same column differ significantly $(\mathrm{P}<0.05)$.

Table 2. The effect of thyme extract, low, medium, and high dose of probiotics on growing rabbit's liver function after 2 months of treatment.

\begin{tabular}{lcccccc}
\hline & AST $(\mathbf{u} / \mathbf{L})$ & ALT $(\mathbf{u} / \mathbf{L})$ & TP $(\mathbf{g} / \mathbf{d L})$ & Alb $(\mathbf{g} / \mathbf{d L})$ & Glob $(\mathbf{g} / \mathbf{d L})$ & A/G \\
\hline Control & $29.54 \pm 0.782 \mathrm{~b}$ & $36.1 \pm 1.006 \mathrm{~b}$ & $6.75 \pm 0.18 \mathrm{bc}$ & $3.98 \pm 0.11 \mathrm{~b}$ & $2.76 \pm 0.07 \mathrm{~b}$ & $1.52 \pm 0.04 \mathrm{a}$ \\
Thyme & $24.95 \pm 0.696 \mathrm{c}$ & $37.15 \pm 0.987 \mathrm{~b}$ & $7.13 \pm 0.19 \mathrm{a}$ & $3.81 \pm 0.10 \mathrm{~b}$ & $3.31 \pm 0.09 \mathrm{a}$ & $1.08 \pm 0.02 \mathrm{~b}$ \\
PBLD & $31.56 \pm 0.886 \mathrm{~b}$ & $41.36 \pm 1.094 \mathrm{~b}$ & $7.51 \pm 0.21 \mathrm{a}$ & $4.45 \pm 0.12 \mathrm{a}$ & $3.06 \pm 0.08 \mathrm{ab}$ & $1.48 \pm 0.04 \mathrm{a}$ \\
PBMD & $32.1 \pm 0.903 \mathrm{ab}$ & $48.3 \pm 1.303 \mathrm{a}$ & $6.45 \pm 0.17 \mathrm{~cd}$ & $3.82 \pm 0.10 \mathrm{~b}$ & $2.63 \pm 0.07 \mathrm{~b}$ & $1.58 \pm 0.04 \mathrm{a}$ \\
PBHD & $34.8 \pm 0.927 \mathrm{a}$ & $36.51 \pm 1.017 \mathrm{~b}$ & $6.26 \pm 0.17 \mathrm{~d}$ & $3.99 \pm 0.11 \mathrm{~b}$ & $2.27 \pm 0.06 \mathrm{~b}$ & $1.81 \pm 0.05 \mathrm{a}$ \\
\hline
\end{tabular}

Data are expressed as Mean \pm S.E.M for 6 rabbits /group.

Theme $=$ Thyme extract $20 \mathrm{mg} / \mathrm{kg}$ b.w, PBLD = Probiotics low dose $20 \mathrm{MBC} / \mathrm{kg}$ b.w, PBMD =Probiotics medium dose,40 MBC/kg b.w) and PBMD Probiotics high dose (PBHD, $60 \mathrm{MBC} / \mathrm{kg} \mathrm{b.w)}$.

$\mathrm{a}, \mathrm{b}, \mathrm{c}, \mathrm{d}$. means having different superscript letters in the same column differ significantly $(\mathrm{P}<0.05)$.

$\mathrm{AST}=$ Aspartate transaminase, $\mathrm{ALT}=$ alanine transaminase, $\mathrm{TP}=$ Serum total protein, $\mathrm{ALB}=$ albumin, $\mathrm{glob}=$ globulin and $\mathrm{A} / \mathrm{G}=$ albumin / globulin ratio. 
3- Thyrotrophic hormones (TSH) and Thyroid hormones (T3 andT4):

Results depicted in Table 3 showed generalized stimulation in $\mathrm{T} 3(\mathrm{P}<0.05)$ for all treatments in compared with control group; at the same time PBHD showed $(\mathrm{P}<0.05)$ markedly increase in $\mathrm{T} 4$ in comparing with control group. On the whole, TSH did not affected by any treatments after the end of experiment.

4- Antioxidant and oxidative stress markers in liver tissue:

Malondialdhyde, reduced glutathione, oxidized glutathione and nitric oxide:

It is clear from Table 4 that PBMD and PBHD showed significant increase $(\mathrm{P}<0.05)$ in $\mathrm{MDA}$, GSSG and NO in comparing with control group with actual mean of $57.25 \pm 1.611(\mathrm{nmol} / \mathrm{g})$ and $63.24 \pm$ $1.685(\mathrm{nmol} / \mathrm{g})$, respectively of MDA and GSSG with actual mean of $2.78 \pm 0.077(\mu \mathrm{mol} / \mathrm{g})$ and 3.26 $\pm 0.086 \mathrm{a}(\mu \mathrm{mol} / \mathrm{g})$, respectively and NO with actual mean of $0.498 \pm 0.014(\mu \mathrm{mol} / \mathrm{g})$ and $0,533 \pm 0.014$
( $\mu \mathrm{mol} / \mathrm{g})$ respectively. That Thyme and PBLD increase endogenous antioxidant substance and decrease oxidative and nitrositve radicals after two months of treatments in comparing with control group. As shown, an increase $(\mathrm{P}<0.05)$ in $\mathrm{GSH}$ treated with Thyme and PBLD in comparing with control group with actual mean of $19.84 \pm 0.527$ $(\mu \mathrm{mol} / \mathrm{g})$ and $16.87 \pm 0.446(\mu \mathrm{mol} / \mathrm{g})$, respectively also PBMD and PBHD markedly decrease GSH in comparing with control group with actual mean of $13.59 \pm 0.367(\mu \mathrm{mol} / \mathrm{g})$ and11.02 $\pm 0.307(\mu \mathrm{mol} / \mathrm{g})$, respectively.

5- Brain serotonin (5-hydroxytryptamine-5HT):

As shown in Figure 1, PBMD and PBHD showed significant $(\mathrm{P}<0.05)$ decrease of 5HT in comparing with control group with actual mean of $0.413 \mu \mathrm{g} / \mathrm{g}$, $0.398 \mu \mathrm{g} / \mathrm{g}$, respectively. Thyme and PBLD treated group increase $(\mathrm{P}<0.05)$ appetite marker $(5 \mathrm{HT})$ in comparing with control group with actual mean $0.632,0.712 \mu \mathrm{g} / \mathrm{g}$, respectively.

Table 3. Effect of thyme extract, low, medium, and high dose of probiotics on growing rabbit's metabolic and appetite function after 2 months of treatment.

\begin{tabular}{lccc}
\hline Groups & $\mathbf{T}_{\mathbf{3}}(\mathbf{p g} / \mathbf{m l})$ & $\mathbf{T}_{\mathbf{4}}(\mathbf{n g} / \mathbf{d l})$ & TSH $(\mathbf{m l U} / \mathbf{l})$ \\
\hline Control & $137 \pm 3.77 \mathrm{~b}$ & $1.94 \pm 0.05 \mathrm{~b}$ & $0.86 \pm 0.02 \mathrm{a}$ \\
Thyme & $145 \pm 4.11 \mathrm{a}$ & $1.86 \pm 0.05 \mathrm{~b}$ & $0.90 \pm 0.02 \mathrm{a}$ \\
PBLD & $147 \pm 4.91 \mathrm{a}$ & $1.81 \pm 0.05 \mathrm{~b}$ & $0.95 \pm 0.02 \mathrm{a}$ \\
PBMD & $145 \pm 3.98 \mathrm{a}$ & $1.97 \pm 0.05 \mathrm{~b}$ & $1.10 \pm 0.03 \mathrm{a}$ \\
PBHD & $130 \pm 3.52 \mathrm{c}$ & $2.64 \pm 0.07 \mathrm{a}$ & $0.92 \pm 0.03 \mathrm{a}$ \\
\hline
\end{tabular}

Data are expressed as Mean \pm S.E.M for 6 rabbits /group.

Thyme $=$ Thyme extract $20 \mathrm{mg} / \mathrm{kg}$ b.w, PBLD = Probiotics low dose $20 \mathrm{MBC} / \mathrm{kg}$ b.w, PBMD =Probiotics medium dose, $40 \mathrm{MBC} / \mathrm{kg}$ b.w) and PBMD Probiotics high dose (PBHD, $60 \mathrm{MBC} / \mathrm{kg} \mathrm{b.w).}$

$\mathrm{a}, \mathrm{b}, \mathrm{c}$. means having different superscript letters in the same column differ significantly $(\mathrm{P}<0.05)$.

$\mathrm{T} 3=$ Triiodothyronine, $\mathrm{T} 4=$ Thyroxin and $\mathrm{TSH}=$ Thyroid stimulating hormone

Table 4. Effect of thyme extract, low, medium, and high dose of probiotics on growing rabbit's oxidative stress markers after 2 months of treatment.

\begin{tabular}{|l|c|c|c|c|}
\hline \multirow{2}{*}{ Groups } & \multicolumn{4}{|c|}{ Parameters } \\
\cline { 2 - 5 } & MDA(nmol/g) & GSH$(\boldsymbol{\mu m o l} / \mathbf{g})$ & $\mathbf{G S S G}(\boldsymbol{\mu m o l} / \mathbf{g})$ & NO(nmol/g) \\
\hline Control & $49.08 \pm 1.299 \mathrm{~b}$ & $15.06 \pm 0.42 \mathrm{bc}$ & $2.08 \pm 0.058 \mathrm{~b}$ & $0.365 \pm 0.01 \mathrm{~b}$ \\
\hline Thyme & $52.5 \pm 1.464 \mathrm{~b}$ & $19.84 \pm 0.527 \mathrm{a}$ & $1.47 \pm 0.04 \mathrm{c}$ & $0.245 \pm 0.007 \mathrm{c}$ \\
\hline PBLD & $48.53 \pm 1.362 \mathrm{~b}$ & $16.87 \pm 0.446 \mathrm{ab}$ & $1.79 \pm 0.051 \mathrm{~b}$ & $0.308 \pm 0.008 \mathrm{~b}$ \\
\hline PBMD & $57.25 \pm 1.611 \mathrm{a}$ & $13.59 \pm 0.367 \mathrm{~cd}$ & $2.78 \pm 0.077 \mathrm{a}$ & $0.498 \pm 0.014 \mathrm{a}$ \\
\hline PBHD & $63.24 \pm 1.685 \mathrm{a}$ & $11.02 \pm 0.307 \mathrm{~d}$ & $3.26 \pm 0.086 \mathrm{a}$ & $0.533 \pm 0.014 \mathrm{a}$ \\
\hline
\end{tabular}

Data are expressed as Mean \pm S.E.M for 6 rabbits /group.

Thyme $=$ Thyme extract $20 \mathrm{mg} / \mathrm{kg}$ b.w, PBLD= Probiotics low dose $20 \mathrm{MBC} / \mathrm{kg}$ b.w, PBMD =Probiotics medium dose,40 MBC/kg b.w) and PBMD Probiotics high dose (PBHD, $60 \mathrm{MBC} / \mathrm{kg}$ b.w).

$\mathrm{a}, \mathrm{b}, \mathrm{c}$. $\mathrm{d}$ means having different superscript letters in the same column differ significantly $(\mathrm{P}<0.05)$.

$\mathrm{MDA}=$ Malondialdhyde, $\mathrm{GSH}=$ reduced glutathione and $\mathrm{GSSG}=$ oxidized glutathione and $\mathrm{NO}=\mathrm{Nitrite} /$ Nitrate level. 


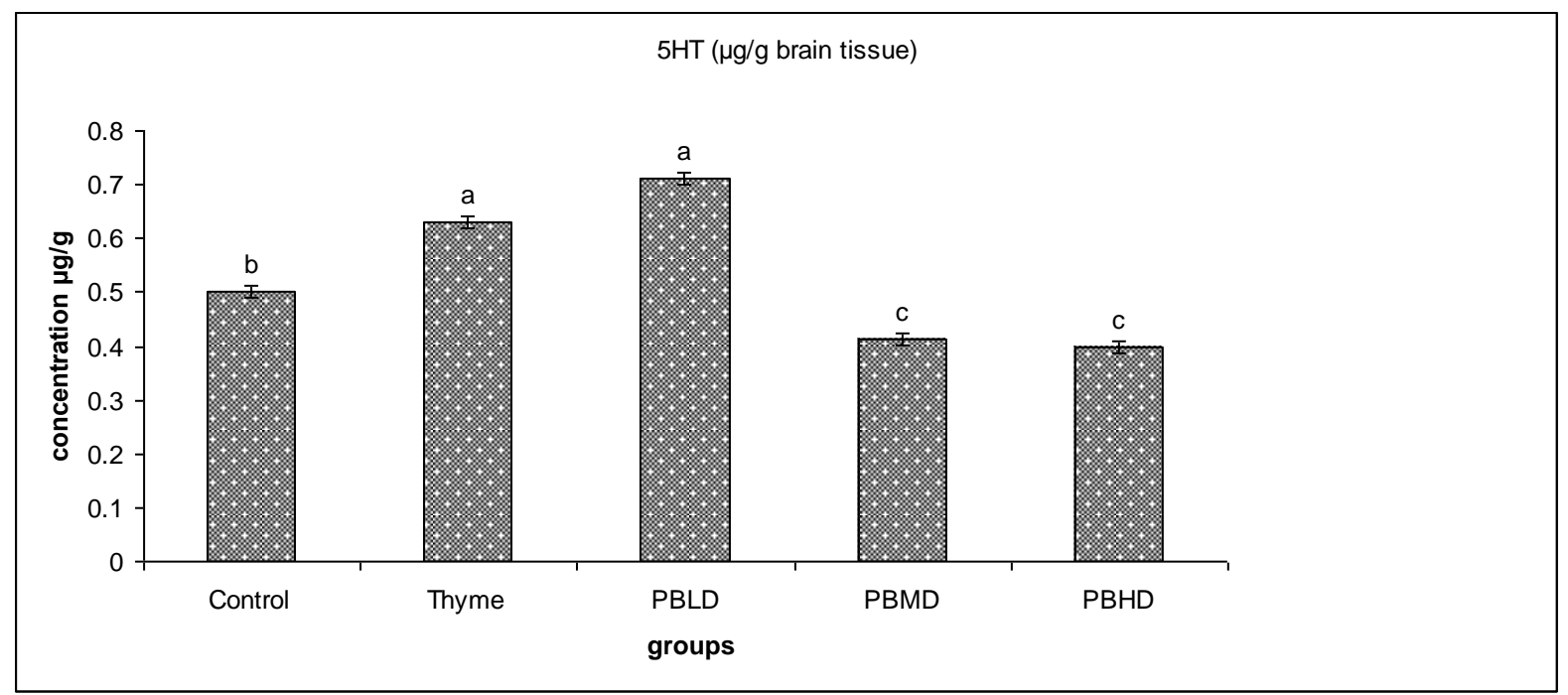

Fig1: Effect of thyme extract, low, medium, and high dose of probiotics on growing rabbit's after 2 months of treatment of Serotonin.

Histopathological examination

Histological examination of liver tissue showed normal hepatocysts for control, thyme, and probiotic low dose. In contrary, probiotics medium and high dose showed alteration in hepatocysts and initial liver manifestation for portal vein and cell leakages.

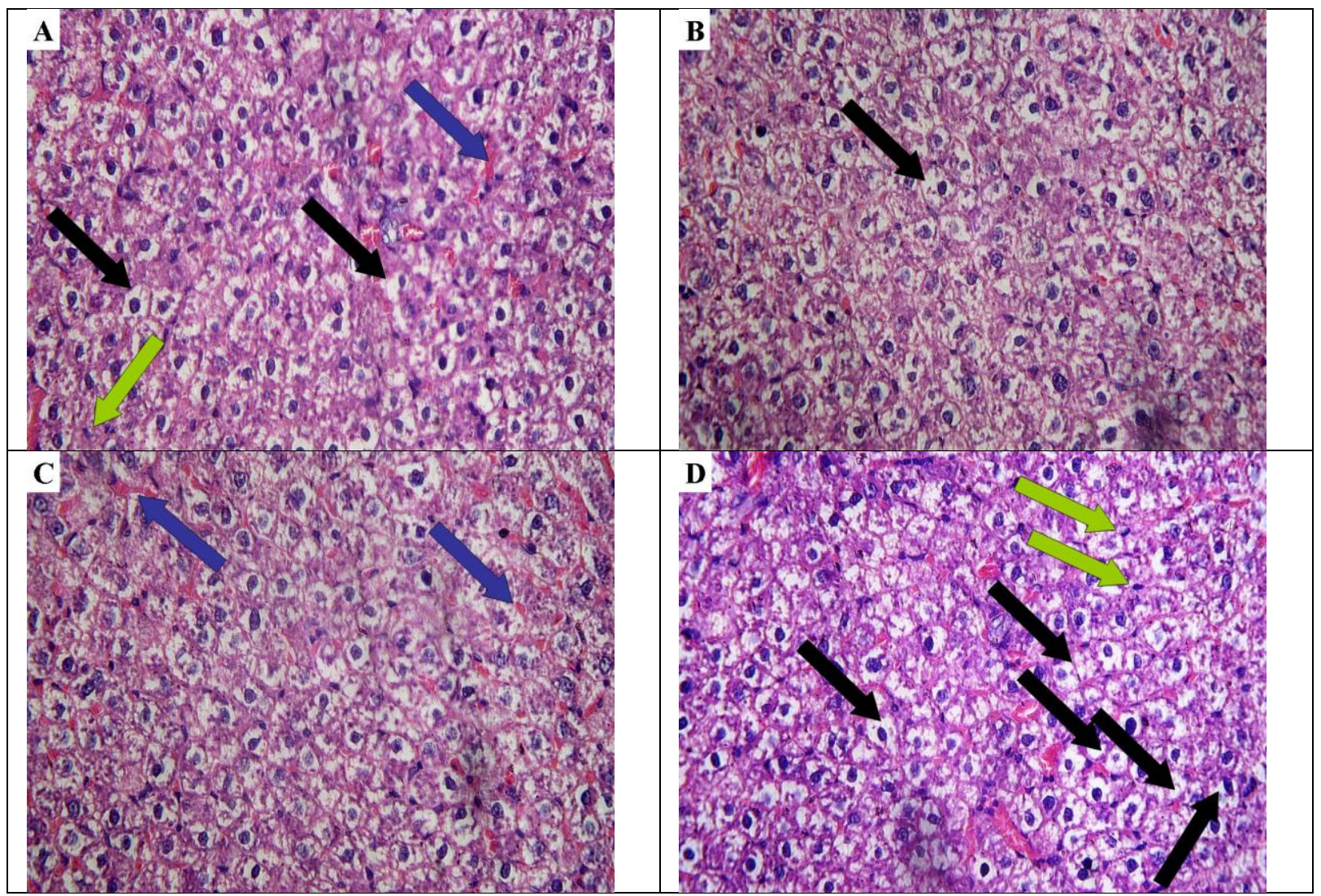




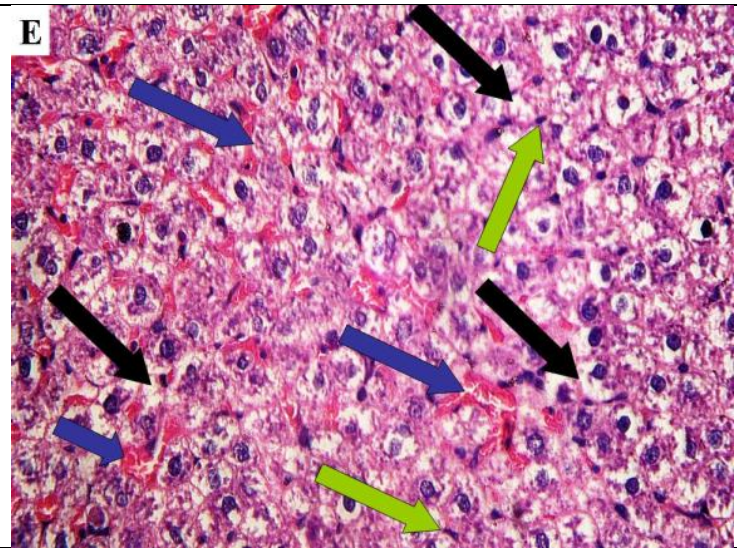

Fig. 2A: Microscopical examination of hepatic tissues in control group revealed mild alterations in hepatocytes vacuolation presented in black arrow, faint congestion and little kupffer cells. Fig. 2 B, C of photomicrographs liver sections showed clear image with normal hepatocytes and modulate most positive alteration due to environmental condition in comparing with control group which reflected in mild congestion, rare of kupffer cell and slight of vacuolation. Fig. 2 D \& E showed that with serial grade from moderate to sever for D and E respectively on hepatocytes alteration. Photomicrographs of liver sections for each group showed sever congestion, leucocytes infiltration and moderate vacuolation.

\section{Discussion}

Probiotics are used to replace the antibiotics in the diet, the zootechnical traits are scarcely improved but with promoting the development and maintenance of the caecal flora. Obtained data demonstrated that the rabbit's body weight and daily weight gain are accelerated for PBLD (20 MBC/kg b.w) and Thyme (20 $\mathrm{mg} / \mathrm{kg} \mathrm{b.w)} \mathrm{group} \mathrm{in} \mathrm{comparing} \mathrm{with} \mathrm{control}$ group, which reflected to potentially utilization of feed intake and best accumulation for nutrients in the body storage pathway. Presented data are in agreement with Pogany et al. (2009), who reported that probiotic stimulate body weight after one month of treatment under heat stress condition for NZW weanling rabbit. Similarly results were obtained by Kritas and Morrison, (2005) who reported that the beneficial effect of probiotic supplementation in broiler diet which increase body weight and feed conversion. The improving in body weight and other weight parameters may due to a natural physiological way and improving digestion by balancing the resident gut microflora as they can improve the integrity of the intestinal mucosal barrier, digestive and immune functions of intestine. Improvement of absorption through intestine of nutrient transportation systems leads to immune resistance and productivity. Thyme vulgaris treated group showed markedly increase in body weight which in consistence with Windisch et al. (2008) who rported that the phytogenics used as additives can stimulate the production of digestive enzymes such as trypsin and amylase, thus providing beneficial effects on nutrient utilization.

The activities of ALT and AST were measured as indicators of hepatocellular damage. The results of present study revealed that there were insignificant changes in ALT and AST activities in treated rabbits with PBLD in compare with control group. Osman and Morgan (2007) reported that the supplementation of Bio-Mos, Bio-Plus or their mixture in rabbit diets reduced liver enzymes (ALT and AST) which associated with a greater improvement in liver enzymes in comparing with un supplemented group. In the enzymatic level of liver tissues the propiotics improved liver function through decreasing serum ALT and AST. On the other hand, high dose of probiotic (PB) markedly inhibited liver function through significantly elevated the liver biomarker enzymes activities, which was reflected by a significant increase in serum levels of AST, ALT, total protein and albumin. Obtained data indicated that PBHD (60 MBC/kg b.w) have stressful effects on the hepatic cells, which are in consistence with Osman and Morgan (2007).

Thyme extract $(20 \mathrm{mg} / \mathrm{kg} \mathrm{b.w})$ may play a protective role against mediated liver injury through its antioxidant and free radical scavenging properties (Loiene et al. 2007) due to the presence of phenolic compounds thymol and carvacrol (Lee and Shibamoto, 2002; Miura et al. 2002).

Obtained data showed the effect of probiotics on thyroid function by generalized stimulation in T3 for treated groups compared with control group, at the same time PBHD (60 MBC/kg b.w.) showed markedly increase $(\mathrm{P}<0.05)$ in $\mathrm{T} 4$ in comparing with control group. On the whole, TSH did not show any effect by different treatments at the end of experiment.

The relationship between the thyroid hormone and body weight is due to responsibility of thyroid metabolic function, as the increase in level of thyroid hormones leads to over stimulation of metabolism which accordingly leads to decrease in body weight, on the other hand the decrease in the level of thyroid hormones leads to inhibition of metabolism which accordingly increases the body weight. (Khan $\boldsymbol{e t}$ al. 2013)

In the present study, Thyme (20 mg $/ \mathrm{kg} \mathrm{b.w)} \mathrm{and}$ PBLD (20 MBC/kg b.w) increased endogenous 
antioxidant substance and decrease oxidative radicals after two months of treatments in comparison with control group due to presence of phenolic phytochemicals in Thyme that posses antioxidant and free radical scavenging effects thereby protecting cellular components against free radical induced damage (El-Nekeety et al., 2011). Moreover, they are likely to possess different antioxidant capacities due to their diverse chemical structures. On the other hand, PBMD (40 MBC/kg b.w) and PBHD (60 $\mathrm{MBC} / \mathrm{kg}$ b.w) showed significant increase $(\mathrm{P}<0.05)$ in Malondialdhyde (MDA), oxidized glutathione (GSSG) and nitric oxide (NO) which may be attributed to the imbalance between oxidant and antioxidant leading to many pathological changes including cellular damage in comparing with control group; also PBMD (40 MBC/kg b.w) and PBHD (60 $\mathrm{MBC} / \mathrm{kg}$ b.w $)$ markedly decrease $(\mathrm{P}<0.05)$ reduced glutathione (GSH) in comparing with control group. Increased malondialdhyde (MDA) level in livers similar biochemical alterations were observed by Cemal et al. (2016) who reported that the failure of the antioxidant defense mechanism is due to the overproduction of free radicals decreased activities of the scavenging enzymes or both. Thyme has antimicrobial and antioxidant properties which effect may due to its active components, enhances appetite and has been reported to promote growth performance ( Hippenstiel et al. 2011. AbdelWareth et al. 2012 Rašković et al. 2015). Moreover, thyme oil can have a beneficial impact on animal performance, health status, and welfare under hot environmental conditions (Attia et al. 2017).

Serotonin is primarily found in the enteric nervous system located in the gastrointestinal tract (GI tract). However, it is also produced in the central nervous system (CNS). Serotonin is the hormone of happiness and appetite improvement, which lead to good food intake and accordingly the improvement in the weight gain (Demir et al. 2008). Our study proved that thyme (20 mg $/ \mathrm{kg} \mathrm{b.w)}$ and PBLD (20 MBC/kg b.w) have a positive effect on the level of serotonin, so good appetite occur and finally good advance in the body weight. In the present study, there were significant differences $(\mathrm{P}<0.05)$ in appetite level resembling in the enhancer of feed intake, there is a difference in favor of the PBLD (20 $\mathrm{MBC} / \mathrm{kg} \mathrm{b.w}$ ) and thyme (20 mg $/ \mathrm{kg} \mathrm{b.w)}$ and in comparing with other groups. This may be attributed to improved digestion and absorption of nutrient in the digestive tract due to the presence of thyme riches with flavonoids, PB (probiotic) riches with Lactobacillus. These findings are consistent with a series of experimental studies (Sims and Sefton, 1999) which revealed that dietary probiotics (Midilli et al., 2008) increase feed intake of broiler chickens. However, it is in contrast with the findings by (Yeo and Kyuil, 1997) who reported that dietary additions of probiotics did not affect feed intake of broiler chickens.

\section{Conclusion}

This study concluded that thymus vulgaris $(20 \mathrm{mg}$ $/ \mathrm{kg} \mathrm{b.w}$ ) and probiotic low dose (20 MBC/kg b.w) have powerful stimulation in physiological and immunological performance after two months of treatments.

\section{Acknowledgment}

The authors are thankful to Dr. Rofanda M. Bakeer, Pathology Department, Medical division, National Research Centre, Egypt, for the kind help in histopathology shoots and comments with the interpretations of the findings.

\section{References}

Abdel-Wareth, A.A., Kehraus, S., Hippenstiel, F., and Südekum, K. H., 2012. Effects of thyme and oregano on growth performance of broilers from 4 to 42 days of age and on microbial counts in crop, small intestine and caecum of 42-day-old broilers. Anim. Feed Sci. Technol, 178:198-202.

Algohary, A.M., Ahmad-Farid, O.A., AbdElrazek, A.M., Al-Baradie, R.S., 2016. Neuroprotective effects of herbal cocktail on cerebrovascular dysfunction in rats with induced hyperhomocysteinaemia. Biomed Res Ther, 3(12): 1045-1061.

Allen, H. K., Levine, U. Y., Looft, T., Bandrick, M., Casey, T. A., 2013. Treatment, promotion, commotion: antibiotic alternatives in foodproducing animals. Trends Microbiol. 21 114119 10.1016/j.tim.2012.11.001.

Attia, $\quad$ Y.A., Attia, A.A., Bakhashwain, N.K., 2017. Bertu Thyme oil (Thyme vulgaris L.) as a natural growth promoter for broiler chickens reared under hot climate. Ital. $\mathrm{J}$.Anim. Sci. 16:275-282.

Banchroft, JD., Stevens, A., Turner, DR., 1996. Theory and Practice of Histological Techniques. Fourth Ed. Churchil Livingstone, New York, London, San Francisco, Tokyo

Bradford, M.M., 1976. A rapid and sensitive method for the quantitation of microgram quantities of protein utilizing the principle of protein-dye binding. analytical biochemistry.72, 248-254.

Cemal, E., Kahveci, R., Gokce, A., Fevzi, M., Kisa, U., Aksoy, N., Cemil, B and Erdogan, B., 2016. Curcumin attenuates inflammation, oxidative stress, and ultrastructural damage induced by spinal cord ischemia- reperfusion injury in rats. Journal of Stroke and Cerebrovascular Diseases. 25, No. 5: 1196-1207.

Demir, E., Kilinc, K., Yildirim, Y., Dincer, F., and Eseceli, H., 2008. Comperative effects of mint, sage, thyme and flavomycin in wheatbased broiler diets. Archive Zootechnica, 11:54-63.

Doumas, B. T., Watson, W. A., and Biggs, H. G., 1971. Albumin standards and the measurement of 
serum albumin with bromcresol green. Clinica. Chimica. Acta.

El-Nekeety, A.A., Mohamed, SR., Hathout, AS. X., Hassan, NS., Aly ,SE., Mosaad, A., and Abdel-Wahhab, A., 2011. Antioxidant properties of Thymus vulgaris oil against aflatoxin-induce oxidative stress in male rats. Toxicon $57984-$ 991.Conditions; Alltech's INC: Selden. NY. USA.

Hippenstiel, F. H. A., Abdel-Wareth, A., Kehraus, S., and Südekum, K. H., 2011. Effects of selected herbs and essential oils, and their active components on feed intake and performance of broilers-A review Arch Geflügelkd, 75: 226-234.

Jayatilleke, E., and Shaw, S., 1993. A high performance liquid chromatographic assay for reduced and oxidized glutathione in biological samples. Anal. Biochem., 214(2): 452-457.

Karalas, F., Karatep, M., and Baysar, A., 2002. Determination of free malondialdehyde in human serum by high performance liquid chromatography. Anal. Biochem.311:76-79.

Karatep, M., 2004. Simulatenous determination of ascorbic acid and free malondialdehyde in human serum by HPLC-UV. Chromatographic Line, 12: 362-365.

Khan, R. U., Rahman, Z. Javed, I., and Muhammad, F., (2013): Supplementation of vitamins, probiotics and proteins on oxidative stress, enzymes and hormones in post-moult male broiler breeders. Archiv Tierzucht 56. 61, 607616.

Kritas, S. K., and Morrison, R. B., 2005. Evaluation of probiotics as a substitute for antibiotics in a large pig nursery. Vet. Rec. 2; 156(14):447-448.

Lee, K.G., and Shibamoto, T., 2002. Determination of antioxidant potential of volatile extracts isolated from various herbs and spices. J. Agric. Food Chem. 50: 4947-4952.

Loiene, K., Petras. VR., Ausra, S., and Juozas, L., 2007. Radical scavenging and antibacterial properties of the extracts from different Thymus pulegioides L. chemotypes. Food Chem. 103 (2): 546-559.

Männer, K., 2011. Effects of a phytogenic feed additive on growth performance and ileal nutrient digestibility in broiler chickens". Poult Sci. 90 (12): 2811-6.

Midilli, M., Alp, M., Kocabağlı, N., Muğlal, OH., Turan, N., Yılmaz, H., and Çakır, S., (2008) Effects of dietary probiotic and prebiotic supplementation on growth performance and serum IgG concentration of broilers. South African Journal of Animal Science. 38 (1): 21-27.

Miura, K., Kikuzaki, H., and Nakatani, N., 2002. Antioxidant activity of chemical components from sage (Salvia officinalis) and thyme (Thymus vulgaris) measured by the oil stability index method. J. Agric. Food Chem. 50: 1845-1851.

Olayemi, F. O., 2007. Evaluation of the reproductive and toxic effects of Cnestis ferruginea de Candolle) root extract in male rats. Ph.D Thesis. Dept. of Physiology, University of Ibadan, 26:

Osman, A.H., and Morgan, A.M., 2007. Immunotoxic Effects of Lambda-Cyhalothrin in Rabbits. J. Egypt. Soc. Toxicol. 36: 23-33.

Pagel, P., Blome, J., and Wolf, HU., 2000. High performance liquid chromatographic separation and measurement of various biogenic compounds possibly involved in the pathomechanism of Parkinson's disease Journal of Chromatography B. 746:297-304.

Papadoyannis, LN., Samanidou, VF. and Nitsos, Ch.C., 1999. Simultaneous determination of nitrite and nitrate in drinking water and human serum by high performance anion-exchange chromatography and UV detection. J. Liq. Chrom. Rel. Technol., 22(13): 2023 - 2041.

Pogany, S.M., Laukova, A., Chrastinova, L., Strompfova, V., Faix, S., Vasilkova, Z., Ondruska, L., Jurcik, R., and Rafay, J., 2009. Enterococcus faecium CCM7420, bacteriocin PPB CCM7420 and their effect in the digestive tract of rabbits. Czech, 54:376-386.

Rašković, A. N., Pavlović, M., Kvrgić, J., Sudji, G., Mitić, Č., 2015. Effects of pharmaceutical formulations containing thyme on carbon tetrachloride induced liver injury in rats. BMC Complement Altern Med.18.15:442.

Reitman, S., and Frankel, S., 1957. A colorimetric method for the determination of serum glutamic oxalacetic and glutamic pyruvic transaminases. Amer. J. Clin. Pathol. 28:56-63.

Richards, J.D., Gong, J., and Lange, De. C.F.M., 2005. The gastrointestinal microbiota and its role in monogastric nutrition and health with an emphasis on pigs: Current understanding, possible modulations, and new technologies for ecological studies. Canadian Journal of Animal Science. 85: 421-435.

SAS, 2004. SAS' Procedure Guide. "Version 6.12 Ed." SAS Institute Inc. Cary, NC, USA.

Saxema, B. B., Demura, H., Gandy, M., and Peterson, R. E., 1968. Determination of steroidal hormones by immunosorbant technique. J. Clin. Endocrinol. Metab., 28: 591-608.

Sims, M.D., and Sefton, A.E., 1999. Comparative effects of mannan oligosaccharide and an antibiotic growth promoter on performance of commercial broilers. Poster presented at the 50 th North Central Avian Disease Conference, Vancouver, British Columbia, Canada.

Thomke, S., and Elwinger, K., 1998. Growth promotants in feeding pigs and poultry ii; mode of action of antibiotic growth promotants. Annales de Zootechnie. 47: 153-167. 
Windisch, W., schedle, K., Plitzner, C., Kroismayr, A., 2008. Use of phytogenic products as feed additives for swine and poultry. J. Anim. Sci., 86, (E.Suppl.), E140-E148.
Yeo, J., and Kyuil, K., 1997. Effect of feeding diets containing an antibiotic, a probiotic, or yucca extract on growth and intestinal urease activity in broiler chicks. Poult. Sci. 76: 381-385.

\section{الاستجابة الفسيولوجية والبيولوجية لبروييوتك ومستحضر نباتى المعطاه كمنشطات نمو على ذكور الأرانب النامية \\ هالة محمد عرام', احمد ابو السعود رضوان', عبد الكريم ابراهيم السيد', فوقية عبد العليم الحضيري², عمر عبد الحميد أحمد فريد²

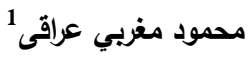

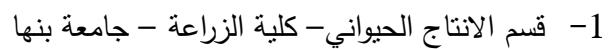

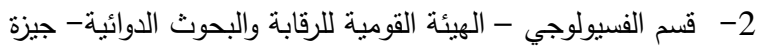

أجريت هذه التجربـة لاراسة تأثثر أفضل منشط نمو على النمو والأداء الفسيولوجي والمناعي المحفز لفطام الأرانب في نهاية فترة

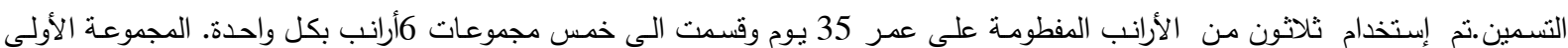

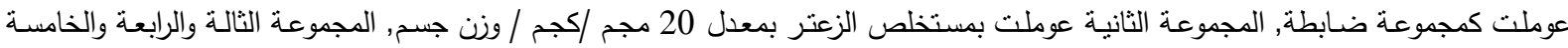
عوملت بالبروبيوتك (Lactobacillus Acidophilus) بمعدل 20-40-60 مليون حمل بكثيري/ كجم وزن جسم على التوالي. واستمرت

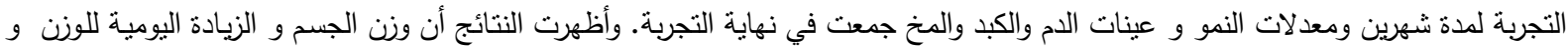
دلاثل الاجهاد التاكسدي ووظائف الكبد والتمثيل الغذائي بشكل عام تم استحثاثهم في الجرعة القليلة من البروبيوتيك (20مليون حمل بكتيري/ كجم التئ

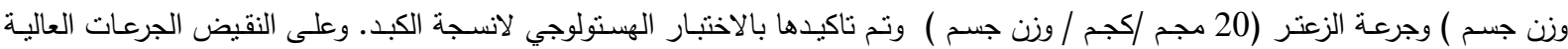

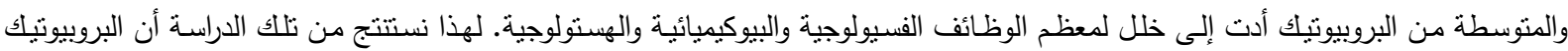
بالجرعات المنخفة و مستخلص الزعتر ذوي تاثيرات عالية في تحسن الأداء الفسيولوجي والمناعي بعد شهرين من المعاملاكلات. الكلمات الدالة: الزعتر , البروبيوتك , الأرنب النيوزيلندى الأبيض , دلائل الإجهاد النأكسدي. 